\title{
Faktor-Faktor Kesulitan Pembelajaran Praktik Karawitan Jawa Program studi Etnomusikologi Fakultas Ilmu Budaya Universitas Mulawarman
}

\author{
Difficulty Factors of Javanese Karawitan Practice Learning in Ethnomusicology Study \\ Program Faculty of Cultural Sciences, Mulawarman University
}

\author{
Aris Setyoko*, Fakultas Ilmu Budaya, Universitas Mulawarman. Email: \\ aris.setyoko@fib.unmul.ac.id
}

Zamrud Whidas Pratama, Fakultas IImu Budaya, Universitas Mulawarman. Email: zamrud.whidas@fib.unmul.ac.id

\author{
Received: \\ 9 Agustus 2021 \\ Accepted: \\ 15 September 2021 \\ Published:
}

30 Oktober 2021

\section{Keywords:}

garap, javanese karawitan, learning

\section{Kata kunci:}

garap, karawitan Jawa, pembelajaran

\begin{abstract}
:
Working on or how to work musically in a musical presentation or composition is an essential element. With the process of working on a musical dish, a good and quality dish will be achieved. The working process is essential to achieve the competency standard of a Javanese musical dish. In learning the practice of Javanese Karawitan, the Ethnomusicology Study Program, Faculty of Cultural Sciences, Mulawarman University, encountered problems in the implementation of this working process. It has an impact on the lack of achievement of learning competency standards. The purpose of this paper is to describe the factors that influence the non-achievement of competency standards in learning Javanese musical practice in terms of working on Javanese karawitan. The method used is descriptive analysis. The data collection technique was done by interview, literature study, and qualitative analysis of the work. The results showed that there were internal and external factors. Internal factors include (1) differences in the cultural background of each student, (2) students have not been able to determine the direction of working on karawitan, and (3) students have not been able to determine the considerations for working on karawitan. The external factor is the learning media used, namely the incomplete Javanese gamelan instrument. It is hoped that the results of this study can be used as material for evaluating learning in Javanese Karawitan practice courses.
\end{abstract}

\begin{abstract}
Abstrak:
Garap atau cara kerja musikal dalam sajian gending atau komposisi karawitan merupakan unsur penting. Dengan adanya proses garap pada sebuah sajian gending karawitan, akan tercapai sebuah sajian yang baik dan berkualitas. Proses garap menjadi hal yang penting untuk mencapai standar kompetensi dari sebuah sajian karawitan Jawa. Pada pembelajaran praktik Karawitan Jawa Program studi Etnomusikologi, Fakultas Ilmu Budaya, Universitas Mulawarman mengalami kendala dalam pelaksanaan proses garap ini. Hal ini berdampak pada belum tercapainya standar kompetensi pembelajarannya. Tujuan penulisan ini adalah untuk mendeskripsikan faktor-faktor yang mempengaruhi tidak tercapainya standar kompetensi dalam pembelajaran praktik karawitan Jawa dalam hal garap pada karawitan Jawa. Metode yang digunakan adalah deskriptif analisis. Teknik pengambilan data dilakukan dengan wawancara, studi pustaka, dan analisis garap karya secara kualitatif. Hasil penelitian menunjukkan terdapat faktor internal dan eksternal. Faktor internal meliputi (1) perbedaan latar belakang budaya setiap mahasiwa, (2) mahasiswa belum bisa dalam menentukan arah garap karawitan, dan (3) mahasiswa belum bisa menentukan pertimbangan garap karawitan. Faktor
\end{abstract}


eksternalnya adalah media pembelajaran yang digunakan, yaitu instrumen gamelan Jawa belum lengkap. Diharapkan dari hasil penelitian ini dapat menjadi bahan evaluasi pembelajaran pada mata kuliah Praktik Karawitan Jawa.

\section{Citation:}

Setyoko, A. \& Pratama, Z. W. (2021). Faktor-Faktor Kesulitan Pembelajaran Praktik Karawitan Jawa Program studi Etnomusikologi Fakultas Ilmu Budaya Universitas Mulawarman. Jurnal Mebang: Kajian Budaya Musik dan Pendidikan Musik, 2(1), 81-92. https://doi.org/10.30872/mebang.v1i2.13

\section{Pendahuluan}

Program studi Etnomusikologi Fakultas Ilmu Budaya Universitas Mulawarman (FIB Unmul) merupakan program studi termuda di bidang kajian Etnomusikologi di seluruh perguruan tinggi di Indonesia. Beberapa perguruan tinggi yang memiliki program studi ini adalah Universitas Sumatera Utara, Institut Kesenian Jakarta, Institut Seni Indonesia Surakarta, dan Institut Seni Indonesia Yogyakarta. Program studi Etnomusikologi FIB Unmul juga merupakan program studi termuda di Fakultas ini setelah program studi Sastra Inggris dan Sastra Indonesia. Program studi Etnomusikologi FIB Unmul mulai menerima mahasiswa baru sebagai angkatan pertamanya, yaitu pada tahun 2014. Program studi Etnomusikologi FIB Unmul mendapatkan izin operasional secara sah pada tanggal 4 Mei 2015 dengan Surat Keputusan Nomor 329/M/Kp/V/2015 dengan pejabat penandatangan Menteri Riset Tekologi dan Pendidikan Tinggi, Mohammad Nasir. Sejak berdiri tahun 2014 sampai tahun 2021, program studi Etnomusikologi FIB Unmul telah memiliki lulusan sebanyak 6 alumni dengan gelar Sarjana Seni (S.Sn.).

Dilihat dari perspektif sosial budaya, kajian etnomusikologi merupakan studi yang melihat musik dalam konteks masyarakat/tingkah laku manusia (Bandem, 2001). Beberapa hal yang dapat ditelaah meliputi fungsi musik bagi masyarakat pendukungnya, peranan musik dalam masyarakat yang memiliki musik tersebut, makna-makna dalam konteks upacara ritual maupun unsur-unsur kepentingan sosial. Secara umum fokus pengkajian studi etnomusikologi menganalisa tentang materi-materi musik itu sendiri yang dapat berupa kajian tentang instrumen musiknya, unsur-unsur musik, struktur komposisi musiknya maupun teknik memainkan instrumennya (Supanggah, 1995). Lahan kajiannya dikhususkan pada musikmusik suku-suku ataupun etnis yang biasanya memiliki daerah geografis tertentu dimana mereka tinggal dan menetap hidup. Sebaran mata kuliah dalam studi etnomusikologi ini pun mengarah terhadap fokus kajian yang dijelaskan di atas. Di program studi Etnomusikologi FIB Unmul, salah satu sebaran mata kuliah yang wajib diambil mahasiswa adalah Praktik Karawitan Jawa. Pada mata kuliah Praktik Karawitan Jawa diajarkan tentang pengenalan bermain gamelan Jawa khususnya gaya Surakarta. Salah satu materi yang dipelajari adalah Lancaran Manyarsewu Laras Pelog Pathet Nem.

Dalam Karawitan Jawa terdapat repertoar lagu atau komposisi musikal yang dimainkan oleh pengrawit atau musisi gamelan (Sumarsam, 2002). Komposisi musikal dalam karawitan disebut dengan istilah gending (Supanggah, 2002). Terdapat bentuk dan struktur di dalam gending. Bentuk gending merupakan format dan ukuran panjang pendeknya kalimat lagu (Waridi, 2006). Sedangkan struktur gending merupakan komponen-komponen pembentuk dari kalimat lagu tersebut. Dalam karawitan, sebuah gending terdiri dari gongan, yaitu sebuah kesatuan lagu dalam karawitan yang diakhiri dengan pukulan instrumen/ricikan gong (Sumarsam, 2003). Dalam setiap gongan terdapat kalimat lagu-kalimat lagu, dalam setiap 
kalimat lagu terdiri dari frasa-frasa, dan setiap frasa terdiri dari nada-nada (Hastanto, 2009). Bentuk dan struktur gending dalam karawitan terbagi menjadi: bentuk dan struktur gending alit, bentuk dan struktur gending ageng, bentuk inggah, bentuk gending pamijen, dan bentuk khusus. Bentuk dan struktur gending alit adalah lancaran, ketawang dan ladrang. Dalam penulisan maupun penyebutannya, kelompok gending alit ini biasanya tanpa mencantumkan/menyebutkan kata "gending". Sebagai contohnya, yaitu Lancaran Manyarsewu, Laras Pelog Pathet Nem. Tidak ada kata "gending" dalam penulisan atau penyebutan jenis gending alit diatas. Bentuk dan struktur gending ageng ditandai dengan penyebutan istilah "kethuk kerep" atau "kethuk arang". Istilah kethuk menyebut salah satu instrumen/ricikan struktural dalam gamelan, sedangkan "kerep" berarti kerap, dan "arang" berarti jarang. Berbeda dengan jenis gending alit diatas dalam penulisan atau penyebutannya. Bentuk dan struktur gending ageng ini menyebutkan kata "gending" disetiap penulisan dan penyebutannya. Sebagai contohnya, yaitu Gending Gambirsawit, Kethuk 2 Kerep minggah 4, Laras Slendro Pathet Sanga. Penulisan maupun penyebutannya menyertakan kata "gending" diawal kalimat. Kethuk kerep dan/atau kethuk arang dalam dunia karawitan disebut dengan istilah merong. Dalam penyajiannya, merong ini tidak dapat berdiri sendiri, sehingga harus dilanjutkan ke bagian berikutnya yang disebut dengan istilah inggah/bentuk inggah. Beragam bentuk dan struktur gending dalam karawitan ini bisa diolah dan disajikan menjadi sebuah pola sajian kerja musikal yang disebut dengan istilah garap.

Dalam dunia karawitan, istilah garap merupakan suatu sistem atau rangkaian kegiatan cara kerja musikal baik dikerjakan secara individu atau sekelompok orang. Rangkaian kegiatan cara kerja musikal ini terdiri dari beberapa tahapan atau kegiatan yang berbeda, dan masingmasing tahapan memiliki cara kerjanya sendiri. Tahapan/kegiatan-kegiatan dengan peran masing-masing ini bekerjasama dalam satu kesatuan untuk menghasilkan sebuah sajian yang disebut dengan istilah gending dalam karawitan. Tahapan/kegiatan-kegiatan dengan peran yang berbeda tersebut saling terkait satu sama lain, saling berinteraksi, dan saling mendukung untuk mewujudkan sajian komposisi musikal/gending tersebut. Garap merupakan salah satu unsur yang terpenting untuk memberi warna, karakter, dan kualitas dalam sebuah sajian gending karawitan. Garap merupakan rangkaian kerja kreatif dari seorang atau sekelompok orang dalam menyajikan sebuah gending atau komposisi musikal karawitan, untuk menghasilkan wujud atau bunyi dengan kualitas atau hasil tertentu sesuai dengan maksud, keperluan atau tujuan dari suatu penyajian karawitan dilakukan.

Sama halnya dengan penyajian Lancaran Manyarsewu Laras Pelog Pathet Nem yang dipraktikkan oleh para mahasiswa program studi Etnomusikologi FIB Unmul. Dengan menganalisis menggunakan aspek garap dalam karawitan seperti yang telah dijabarkan tersebut, dapat dideskripsikan bagaimana standar kompetensi yang telah dicapai pada mata kuliah Praktik Karawitan Jawa program studi Etnomusikologi FIB Unmul. Selanjutnya dituliskan pertanyaan penelitiannya, yaitu faktor-faktor kesulitan apa saja yang mempengaruhi tidak tercapainya standar kompetensi pada pembelajaran Praktik Karawitan Jawa program studi Etnomusikologi FIB Unmul. Tujuan penelitian ini adalah untuk mengetahui dan mendeskripsikan faktor-faktor yang mempengaruhi tidak tercapainya standar kompetensi dalam pembelajaran Praktik Karawitan Jawa dalam hal garap dan menjelaskan bagaimana garap/cara kerja musikal pada setiap ricikan/instrumen dalam gamelan Jawa pada pembelajaran Praktik Karawitan Jawa program studi Etnomusikologi FIB Unmul. Dengan penelitan ini diharapkan memberikan manfaat terhadap peningkatan standar kompetensi 
pembelajaran Praktik Karawitan Jawa dan dapat menjadi bahan evaluasi pembelajaran pada mata kuliah Praktik Karawitan Jawa kedepannya.

\section{Metode}

Metode penelitian yang digunakan dalam penelitian ini adalah deskriptif analisis dengan pendekatan kualitatif, membuat penjelasan atau gambaran yang ada mengenai data-data pada objek penelitian. Pendekatan kualitatif ini menurut Sadikin (Bogdan \& Biklen, 1982) memiliki karakteristik sebagai berikut: (1) sumber data langsung dalam situasi wajar, (2) bersifat deskriptif, (3) mengutamakan proses dari pada produk atau hasil, (4) analisis data secara deskriptif, dan (5) mengutamakan makna. Data-data yang diperoleh dalam penelitian kemudian disusun, dijelaskan, dianalisa berdasarkan teori yang ada untuk selanjutnya ditarik kesimpulannya (Surachmad, 1985). Situasi yang wajar merujuk kepada proses serta aktivitas pada saat pengumpulan informasi melalui observasi terhadap situasi dan manusia yang diobservasi.

Bentuk penelitian ini adalah kualitatif bercirikan deskriptif analitik, dimaksudkan untuk memperoleh gambaran tentang status gejala pada saat penelitian atau untuk melihat kondisi terhadap apa yang ada dalam situasi (Winarno, 1982; dan Best, 1989). Dalam penelitian ini data diperoleh dengan melakukan pengamatan, observasi, wawancara, dokumentasi penelitian, dan data-data lainnya yang dibutuhkan sebagai instrumen penelitian. Alasan menggunakan metode penelitian ini didasarkan pada pertimbangan bahwa metode ini dianggap sangat relevan dengan materi penulisan ini.

Konsep garap karawitan yang dicetuskan oleh Rahayu Supanggah menjadi pisau bedah dalam menganalisis pembelajaran Praktik Karawitan Jawa program studi Etnomusikologi FIB Unmul ini. Supanggah menjelaskan bahwa konsep garap merupakan sebuah sistem yang melibatkan unsur-unsur atau pihak-pihak yang masing-masing saling terkait dan membantu dalam mewujudkan sebuah sajian gending dalam karawitan. Beberapa unsur garap tersebut dalam karawitan Jawa adalah sebagai berikut: materi garap atau ajang garap, penggarap, sarana garap, perabot atau piranti garap, penentu garap, dan pertimbangan garap.

Materi garap atau ajang garap dalam dunia karawitan berhubungan dengan balungan gending/notasi gending atau lagu vokal yang digunakan sebagai acuan pengrawit/musisi gamelan dalam memainkan gamelan. Istilah balungan gending merupakan istilah yang digunakan untuk menyebut notasi dalam karawitan, baik teoritis, praktik, terutama dalam pembelajaran ataupun analisis musikal. Beberapa etnomusikilog seperti Kunst, Hood, dan Becker mengganggap bahwa ricikan balungan merupakan instrumen yang memainkan balungan gending, yang identik dengan lagu saron, demung, slenthem, atau bonang penembung. Agak sedikit berbeda dengan pendapat para peneliti karawitan Jawa seperti salah satunya Supanggah yang menyebut bahwa balungan gending adalah notasi atau catatan gending yang tertulis pada buku-buku atau catatan-catatan gending yang digunakan para pengrawit/musisi gamelan. Untuk kepentingan analisis karawitan dalam berbagai keperluan dan tujuan seperti untuk pembelajaran, peyajian karawitan, serta pendokumentasian karawitan, sangat diperlukan dan dibutuhkan balungan gending/notasi karawitan ini.

Penggarap disini berarti adalah seniman penggarap/pengrawit/musisi gamelan yang memberikan olah dan tafsir terhadap balungan gending/notasi karawitan menjadi sebuah sajian gending/lagu karawitan. Peranan pengrawit/musisi gamelan sangat menentukan dan dominan dalam menentukan hasil suatu penyajian karawitan. Pengrawit/musisi gamelan 
merupakan unsur garap yang paling penting dan menentukan (Supanggah, 2009). Sarana garap adalah alat yang digunakan oleh pengrawit/musisi karawitan sebagai media untuk menyampaikan ide/gagasan musikal atau mengekspresikan diri kepada audience/tanpa audience, termasuk kepada diri sendiri atau lingkungan sendiri. Media ungkap atau sarana garap dalam dunia karawitan adalah ricikan/instrumen gamelan.

Supanggah menjelaskan bahwa perabot garap atau piranti garap merupakan sebuah tools, perangkat lunak yang sifatnya imajiner/abstrak berada dalam benak pengrawit/musisi gamelan. Perangkat lunak atau tools tersebut bisa berwujud gagasan atau sebuah ide vokabuler garap yang telah terbentuk oleh tradisi atau kebiasaan yang dilakukan oleh para pengrawit/musisi gamelan. Dalam konvensi karawitan tradisional, komposisi karawitan berwujud dari kerangka gending yang disebut dengan balungan gending dan/atau lagu-lagu atau tembang (Supanggah, 2009). Komposisi karawitan tersebut dimainkan dalam ricikan/instrumen gamelan, dalam eksekusinya lebih banyak diserahkan kepada kebijakan dan kebijaksanaan para pengrawit/musisi gamelannya. Pada saat menghadirkan atau merealisasikan komposisi karawitan/gending pada ricikan/instrumen gamelan tersebut, para musisi gamelan menggunakan perabot garap/piranti garap yang berupa perbendaharaan/vokabuler garap. Perabot garap atau piranti garap yang berupa perbendaharaan/vokabuler garap dalam karawitan ini merupakan hasil akumulasi perjalanan sejarah berpraktik karawitan. Supanggah menyebutkan perabot/piranti garap dapat dikelompokkan menjadi beberapa golongan, yaitu teknik, pola, irama dan laya, laras, dan pathet.

Garap dalam karawitan tradisi gaya Surakarta merupakan unsur yang sangat penting dalam menentukan hasil, karakter, dan kualitas dari sajian sebuah gending. Dimana sebuah gending ini baru bisa terlihat eksis setelah instrumen-instrumen gamelan maupun vokal dimainkan bersama oleh pengrawit/musisi gamelan. Kemudian terdapat balungan gending/notasi gending dan lagu dalam karawitan sebenarnya merupakan bahan mentah yang perlu diolah, ditafsir, dan digarap lebih lanjut oleh para pengrawit/musisi gamelan, menjadi sebuah sajian musikal yang siap dinikmati, yang disebut dengan gending. Musisi gamelan/pengrawit dengan segala latar belakangnya memiliki peranan dominan dalam menafsirkan, mengolah, dan menggarap gending, kemudian menentukan piranti/perabot garap dalam menggarap balungan gending/notasi gending (Supanggah, 2009). Dalam menggarap gending, seorang musisi gamelan/pengrawit memiliki peluang garap yang luas baik dengan menggunakan vokabuler dan/atau unsur garap yang sudah ada maupun membuat yang baru. Seluas-luasnya peluang garap bagi pengrawit/musisi gamelan, secara tradisi mereka dibatasi oleh rambu-rambu atau kaidah-kaidah estetik sampai kadar tertentu. Rambu-rambu ini yang secara konvensi tradisi, besar peranannya dalam menentukan garap dalam karawitan Jawa gaya Surakarta. Ramburambu yang menentukan garap dalam karawitan berkaitan dengan fungsi untuk apa atau dalam rangka apa suatu gending disajikan dan dimainkan.

Supanggah (2009) menyebutkan bahwa pertimbangan garap merupakan hal yang mempengaruhi musisi gamelan/pengrawit dalam melakukan garap. Perbedaannya dengan penentu garap adalah pada bobotnya. Pertimbangan garap lebih bersifat accidental, kadangkadang bisa sangat mendadak dan pilihan garapnya pun mana suka/sedapatnya apa yang muncul pada saat itu. Sebagai contoh kasus bentuk pertimbangan garap dalam karawitan adalah sebagai berikut. Dalam sebuah pertunjukan karawitan Jawa, idealnya dapat menghasilkan sajian gending yang optimal baik dalam pilihan repertoar, garap repertoar, kualitas hasil, konteks sosialnya. Selain itu juga bagaimana gamelan yang digunakan benar- 
benar berkualtias, musisi gamelan/pengrawitnya yang mumpuni/hebat dalam bermain musiknya, fasilitas pendukung pertunjukan yang memadai. Saat di lapangan, pada kenyataannya hal-hal tersebut di atas tidak mudah diwujudkan atau direalisasikan. Pada akhirnya, musisi gamelan/pengrawit dituntut untuk bisa menyesuaikan dengan keadaan/keterbatasan sarana penunjang tersebut dengan melakukan pertimbanganpertimbangan garap ini.

\section{Hasil dan pembahasan}

Selain pengamatan penulis di lapangan, wawancara adalah sumber informasi orisinil. Kami berusaha memberikan ruang bagi narasumber untuk menyuarakan pemikiran mereka yang relevan. Narasumber pada penelitian ini adalah para mahasiswa program studi Etnomusikologi FIB Unmul angkatan 2017. Berdasarkan data-data temuan dan fakta-fakta di lapangan, penulis akan menjabarkan dan sekaligus menganalis pada bagian-bagian yang dianggap memerlukan pembahasan lebih lanjut mengenai unsur-unsur konsep garap dalam karawitan Jawa. Unsur garap tersebut dalam karawitan Jawa adalah materi garap atau ajang garap, penggarap, sarana garap, perabot atau piranti garap, penentu garap, dan pertimbangan garap.

\subsection{Materi Garap/Ajang Garap}

Materi garap atau ajang garap dalam dunia karawitan berhubungan dengan balungan gending/notasi gending atau lagu vokal yang digunakan sebagai acuan pengrawit/musisi gamelan dalam memainkan repertoar lagu/gending gamelan. Pengrawit/musisi gamelan dalam hal ini adalah para mahasiswa Program studi Etnomusikologi FIB Unmul yang mengambil mata kuliah Praktik Karawitan Jawa. Berikut adalah balungan gending/notasi: Lancaran Manyarsewu Laras Pelog Pathet Nem, yang digunakan dalam pembelajaran Praktik Karawitan Jawa.

\section{NOTASI/BALUNGAN GENDING DAN NOTASI KENDANG LANCARAN MANYARSEWU LARAS PELOG PATHET NEM}

\section{NOTASI/BALUNGAN GENDING:}

Buka: $\ldots . . ! .6 \quad . ! .6 \quad .5 .93$
A. $\quad\left[\begin{array}{lllll}.5 .3 & .5 .3 & .5 .3 & .6 .95\end{array}\right.$
B. $\quad .6 .5 \quad .6 .5 \quad .6 .5 \quad .3 .82$
C. $\quad .3 .2 \quad .3 .2 \quad .3 .2 \quad . ! . g 6$
D. $\quad . ! .6 \quad . ! .6 \quad . ! .6 \quad .5 .83]$ 


\section{NOTASI KENDANG:}

Buka: $\quad \ldots \quad \ldots$ IIP B .P.gP
A. $\quad$.P.P .P.P .P.P .P.gP
B. $\quad\left[\begin{array}{lllll}P P P P & P B P P & P B P P & P B P g P\end{array}\right]$
$P$ B J gl -. $\rightarrow$ Ke suwuk/berhenti: pola $D$
C. $\quad$ BPPB PPBP PBPP PBPgP
D. P.P. PBP. BP.B.PPg.

Dengan tersedianya notasi balungan gending dan notasi kendang yang digunakan para mahasiswa untuk bermain gamelan seperti nampak diatas, dapat dikatakan bahwa pada pembelajaran Praktik Karawitan Jawa ini telah memenuhi salah satu unsur garap dalam karawitan.

\subsection{Penggarap Gending dan Penentu Garap Gending.}

Penggarap gending adalah seniman penggarap/pengrawit/musisi gamelan yang sekaligus sebagai penentu garap gending yang memberikan olah dan tafsir terhadap balungan gending/notasi karawitan menjadi sebuah sajian gending/lagu karawitan. Pada unsur ini musisi gamelan/pengrawit dengan latar belakangnya memiliki peranan dominan dalam menafsirkan, mengolah, dan menggarap gending, kemudian menentukan piranti/perabot garap dalam menggarap balungan gending/notasi gending. Dalam penelitian ini, penggarap materi/ajang garap adalah para mahasiswa program studi Etnomusikologi yang mengikuti pembelajaran/perkuliahan Praktik Karawitan Jawa. Dari hasil wawancara yang dilakukan penulis kepada para mahasiswa yang mengambil mata kuliah Praktik Karawitan Jawa, ditemukan bahwa kebanyakan dari mereka berlatarbelakang budaya non Jawa, yang kurang pengetahuannya tentang bermain gamelan Jawa. Beberapa mahasiswa berasal dari suku Dayak, Kutai, Banjar, Paser dan campuran beberapa suku. Hal ini akan berpengaruh terhadap kemampuan dalam memberikan olah dan tafsir dalam mereka bermain gamelan. Pengetahuan dasar mengenai bermain gamelan setidaknya dikuasi terlebih dahulu untuk bisa memberikan olah dan tafsir dalam menentukan garap permainan gamelan yang notabene berasal dari wilayah Jawa.

\subsection{Sarana Garap Gending}

Sarana garap adalah alat yang digunakan oleh pengrawit/musisi karawitan sebagai media ungkap untuk menyajikan gending. Media ungkap atau sarana garap yang digunakan dalam pembelajaran Praktik Karawitan Jawa program studi Etnomusikologi adalah seperangkat gamelan Jawa berlaras slendro dan pelog.

Berdasarkan pengamatan di lapangan, perangkat gamelan Jawa yang dimiliki oleh program studi Etnomusikologi FIB Unmul ini merupakan perangkat gamelan yang tidak lengkap seperti gamelan Jawa pada umumnya. Berikut instrumen-instrumen gamelan yang dimiliki program studi Etnomusikologi FIB Unmul: Bonang Barung berlaras slendro dan pelog, 
dua buah Demung, dua buah Saron, dua buah Slentem, tiga buah Gender barung, dua buah Gambang, dua buah Kempul, satu buah instrumen Gong, satu buah Kendang Penunthung, satu buah Kendang Ageng, dan satu buah Kendang Ciblon. Dengan terbatasnya instrumen gamelan tersebut berakibat pada kurang maksimalnya dalam penggarapan Lancaran Manyarsewu yang menjadi materi pada pembelajaran praktik Karawitan Jawa. Hal ini berarti belum terpenuhinya pada bagian unsur garap karawitan ini

\subsection{Perabot/Piranti Garap}

Supanggah menyebutkan perabot/piranti garap dapat dikelompokkan menjadi beberapa golongan, yaitu teknik, pola, irama dan laya, laras, dan pathet. Berkaitan dengan beberapa golongan perabot/piranti garap, pada bagian ini dideskripsikan gambaran dan penjabaran tentang garap musikal pada setiap instrumen gamelan yang digunakan dalam pembelajaran Praktik Karawitan Jawa, program studi Etnomusikologi FIB Unmul berkaitan dengan teknik, pola, irama dan laya.

Lancaran Manyarsewu pada pembelajaan Praktik Karawitan Jawa ini menggunakan Laras Pelog dan Pathet Nem. Instrumen gamelan yang digunakan dalam pembelajaran Praktik Karawitan Jawa ini adalah: Instrumen Bonang Barung, Kendang Penunthung, Kendang Ageng, Saron, Demung, Slenthem, Kempul dan Gong. Berikut dijabarkan garap musikal setiap ricikan/instrumen gamelan yang di gunakan pada pembelajaran Praktik Karawitan Jawa program studi Etnomusikologi FlB Unmul.

\section{Tabel 1. Garap Bagian Buka'}

\begin{tabular}{|c|c|}
\hline Notasi/Balungan Gending & $\begin{array}{lllll}\ldots \ldots & . ! .6 & . ! .6 & .5 .3 \\
\end{array}$ \\
\hline BONANG & $\ldots \quad . ! .6 \quad . ! .6 \quad 3.3$. \\
\hline KENDANG & $\ldots \ldots, \ldots$ IIPB $. P . P$ \\
\hline SARON & $\begin{array}{llll}\ldots & \ldots & \ldots & \ldots 3\end{array}$ \\
\hline DEMUNG DAN SLENTEM & $\begin{array}{llll}\ldots & \ldots & \ldots & \ldots 3 \\
\end{array}$ \\
\hline KEMPUL & $\begin{array}{llll}\ldots & \ldots & \ldots & \ldots\end{array}$ \\
\hline GONG & $\begin{array}{lll}\ldots & \ldots \ldots & \ldots \\
\end{array}$ \\
\hline
\end{tabular}

Tabel 2. Garap Bagian (A) ${ }^{2}$

\begin{tabular}{|c|c|}
\hline Notasi/Balungan Gending & $\begin{array}{lllll}.5 .3 & .5 .3 & .5 .3 & .6 .5\end{array}$ \\
\hline BONANG & 3.3 .3 .3 .3 .3 .5 .5$. \\
\hline KENDANG & .P.P .P.P .P.P .P.P \\
\hline SARON & $3553 \quad 3553 \quad 3553 \quad 3665$ \\
\hline DEMUNG DAN SLENTEM & $\begin{array}{lllll}5.3 & .5 .3 & .5 .3 & .6 .5 \\
\end{array}$ \\
\hline KEMPUL & $\ldots \ldots . . P \ldots, P \ldots \quad . P$. \\
\hline GONG & $\begin{array}{lllll}\ldots & \ldots & \ldots & \ldots g \\
\end{array}$ \\
\hline
\end{tabular}

${ }^{1}$ Garap bagian buka ini hanya dilakukan sekali saja (tidak ada pengulangan).

${ }^{2}$ Garap bagian (A) ini hanya dilakukan sekali saja (tidak ada pengulangan). 
Tabel 3. Garap Bagian A

\begin{tabular}{|c|c|}
\hline Notasi/Balungan Gending & $\begin{array}{llllll}5.3 & .5 .3 & .5 .3 & .6 .5\end{array}$ \\
\hline BONANG & 3.3 .3 .3 .3 .3 .5 .5$. \\
\hline KENDANG & $\begin{array}{llll}P P P P & P B P P & P B P P & P B P P\end{array}$ \\
\hline SARON & $3553 \quad 3553 \quad 3553 \quad 3665$ \\
\hline DEMUNG DAN SLENTEM & $\begin{array}{lllll}.5 .3 & .5 .3 & .5 .3 & .6 .5\end{array}$ \\
\hline KEMPUL & $\begin{array}{llll}\ldots & . P \ldots & . P \ldots & . P \ldots\end{array}$ \\
\hline GONG & $\ldots \ldots$ \\
\hline
\end{tabular}

\section{Tabel 4. Garap Bagian B}

\begin{tabular}{|c|c|}
\hline Notasi/Balungan Gending & $\begin{array}{lllll}.6 .5 & .6 .5 & .6 .5 & .3 .2 \\
\end{array}$ \\
\hline BONANG & 5.5 .5 .5 .5 .5 .2 .2$. \\
\hline KENDANG & $\begin{array}{lllll}P P P P & P B P P & P B P P & P B P P\end{array}$ \\
\hline SARON & $\begin{array}{llll}5665 & 5665 & 5665 & 5332\end{array}$ \\
\hline DEMUNG DAN SLENTEM & $\begin{array}{lllll}.6 .5 & .6 .5 & .6 .5 & .3 .2\end{array}$ \\
\hline KEMPUL & $P_{\ldots} . P_{\ldots}$ \\
\hline GONG & g. \\
\hline
\end{tabular}

\section{Tabel 5. Garap Bagian C}

\begin{tabular}{|c|c|}
\hline Notasi/Balungan Gending & $.3 .2 \quad .3 .2 \quad .3 .2 \quad . ! .6$ \\
\hline BONANG & 2.2. 2.2. 2.2.6.6. \\
\hline KENDANG & $\begin{array}{llll}P P P P & P B P P & P B P P & P B P P\end{array}$ \\
\hline SARON & $2332 \quad 2332 \quad 2332 \quad 2116$ \\
\hline DEMUNG DAN SLENTEM & $\begin{array}{lllll}.3 .2 & .3 .2 & .3 .2 & .1 .6\end{array}$ \\
\hline KEMPUL & 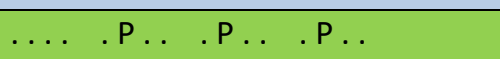 \\
\hline GONG & 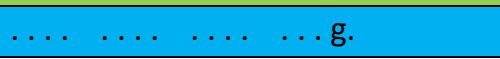 \\
\hline
\end{tabular}

Tabel 6. Garap Bagian D

\begin{tabular}{|c|c|}
\hline Notasi/Balungan Gending & $.1 .6 \quad 1.6 \quad .1 .6 \quad .5 .3$ \\
\hline BONANG & 6.6 .6 .6 .6 .6 .3 .3$. \\
\hline KENDANG & $\begin{array}{llll}B P P B & P P B P & \text { PBPP } & \text { PBPP }\end{array}$ \\
\hline SARON & $6556 \quad 6556 \quad 6556 \quad 6553$ \\
\hline DEMUNG DAN SLENTEM & $\begin{array}{lllll}.1 .6 & .1 .6 & .1 .6 & .5 .3 \\
\end{array}$ \\
\hline KEMPUL & $\ldots . P \ldots . P \ldots \quad . P \ldots$ \\
\hline GONG & $\ldots \quad \ldots g$. \\
\hline
\end{tabular}


Tabel 7. Garap Bagian C Menuju Suwuk/Berhenti ${ }^{3}$

\begin{tabular}{|c|c|}
\hline Notasi/Balungan Gending & $.3 .2 \quad .3 .2 \quad .3 .2 \quad . ! .6$ \\
\hline BONANG & 2.2 .2 .2 .2 .2 .6 .6$. \\
\hline KENDANG & $\begin{array}{lllll}\text { PPPP } & \text { PBPP } & \text { PBPP } & \text { PBJI }\end{array}$ \\
\hline SARON & $2332 \quad 2332 \quad 2332 \quad 2116$ \\
\hline DEMUNG DAN SLENTEM & $.3 .2 \quad .3 .2 \quad .3 .2 \quad .1 .6$ \\
\hline KEMPUL & $\ldots . . P$ \\
\hline GONG & g. \\
\hline
\end{tabular}

Tabel 8. Garap Bagian D Suwuk/Berhenti ${ }^{4}$

\begin{tabular}{|c|c|}
\hline Notasi/Balungan Gending & $\begin{array}{lllll}.6 & . & .6 & . ! .6 & .5 .3\end{array}$ \\
\hline BONANG & 6.6 .6 .6 .6 .6 .3 .33 \\
\hline KENDANG & P.P. PBP. BP.B. .PP. \\
\hline SARON & $6556 \quad 6556 \quad 6556 \quad 6553$ \\
\hline DEMUNG DAN SLENTEM & $\begin{array}{lllll}.1 .6 & .1 .6 & .1 .6 & .5 .3\end{array}$ \\
\hline KEMPUL & $\ldots . P \ldots \quad . P \ldots \quad . P \ldots$ \\
\hline GONG & $\begin{array}{llll}\ldots & \ldots & \ldots & \ldots g \\
\end{array}$ \\
\hline
\end{tabular}

Penjelasan jalannya sajian notasi garap pada setiap ricikan/instrumen gamelan.

$\begin{array}{ll}\text { PUTARAN } 1 & : \text { Tabel } 1 \rightarrow \text { Tabel } 2 \rightarrow \text { Tabel } 4 \rightarrow \text { Tabel } 5 \rightarrow \text { Tabel } 6 \\ \underline{\text { PUTARAN } 2} & : \text { Tabel } 3 \rightarrow \text { Tabel } 4 \rightarrow \text { Tabel } 5 \rightarrow \text { Tabel } 6 \\ \text { PUTARAN } 3 & : \text { Tabel } 3 \rightarrow \text { Tabel } 4 \rightarrow \text { Tabel } 5 \rightarrow \text { Tabel } 6 \\ \underline{\text { PUTARAN } 4} & : \text { Tabel } 3 \rightarrow \text { Tabel } 4 \rightarrow \text { Tabel } 5 \rightarrow \text { Tabel } 6 \\ \underline{\text { PUTARAN } 5} & : \text { Tabel } 3 \rightarrow \text { Tabel } 4 \rightarrow \text { Tabel } 5 \rightarrow \text { Tabel } 6 \\ \underline{\text { PUTARAN } 6} & : \text { Tabel } 3 \rightarrow \text { Tabel } 4 \rightarrow \text { Tabel } 5 \rightarrow \text { Tabel } 6 \\ \text { PUTARAN } 7 & : \text { Tbael } 3 \rightarrow \text { Tabel } 4 \rightarrow \text { Tabel } 7 \rightarrow \text { Tabel } 8\end{array}$

Catatan: Cetak tebal hanya dilakukan sekali dalam sajian gending.

Berdasarkan data diatas yang telah tersedianya beberapa perabot atau piranti garap dalam memainkan Lancaran Manyarsewu Laras Pelog Pathet Nem, terlihat bahwa setidaknya sudah sedikit terpenuhi salah satu unsur garap dalam karawitan yang dijadikan standar kompetensi dalam tersajikannya sebuah gending karawitan. Penulis katakan sedikit terpenuhi dikarenakan masih banyak lagi kategori yang harus terpenuhi dalam unsur ini. Misalnya, Perangkat lunak atau tools untuk bisa mewujudkan gagasan atau sebuah ide vokabuler garap tersebut biasanya telah terbentuk oleh tradisi, kebiasaan, dan pengalaman yang telah dilakukan oleh para pengrawit/musisi gamelan. Dalam hal ini, para mahasiswa yang notabene adalah kebanyakan berlatar belakang non Jawa belum memiliki kemampuan ini. Para mahasiswa ini hanya

\footnotetext{
3 Garap bagian C menuju suwuk/berhenti ini hanya dilakukan sekali saja saat gending akan suwuk/berhenti/selesai sajiannya.

${ }^{4}$ Garap bagian D suwuk/berhenti ini hanya dilakukan sekali saja, sajian gending selesai.
} 
memainkan gamelan sesuai notasi yang diberikan oleh pengajarnya dan belum bisa memberikan gagasan atau ide vokabuler garap karawitan.

\subsection{Pertimbangan Garap Gending}

Dalam sebuah penyajian pertunjukan karawitan Jawa, idealnya dapat menghasilkan sajian gending yang optimal baik dalam pilihan repertoar, garap repertoar, kualitas hasil, dan konteks sosialnya. Selain itu juga bagaimana gamelan yang digunakan benar-benar berkualitas, musisi gamelan/pengrawit-nya yang mumpuni/hebat dalam bermain musiknya, fasilitas pendukung pertunjukan yang memadai. Saat di lapangan, pada kenyataannya hal-hal tersebut di atas tidak mudah diwujudkan atau direalisasikan. Pada akhirnya, musisi gamelan/pengrawit dituntut untuk bisa menyesuaikan dengan keadaan/keterbatasan sarana penunjang tersebut dengan melakukan pertimbangan-pertimbangan garap.

Dilihat pada kasus ini, pertimbangan garap sebagian besar belum terpenuhi. Sajian Lancaran Manyarsewu belum bisa tersajikan secara ideal dikarenakan musisi gamelan yang belum mumpuni dan belum bisa menyesuaikan dengan keadaan dalam pertimbangan menggarap gending, fasilitas pendukung khususnya gamelan yang belum berkualitas serta masih minim instrumen yang di gunakan dalam pembelajaran. Selanjutnya, penggarapan Lancaran Manyarsewu ini hanya dimainkan dalam satu tingkatan garap irama saja, yaitu irama lancar, yang sebenarnya bisa dilakukan dalam tiga tingkatan garap irama, yaitu irama lancar, tanggung dan dadi. Dari segi hasil suara yang ditimbulkan dari instrumen gamelan yang digunakan sangat jauh dari harapan dikarenakan instrumen gamelan yang sudah blero/fals. Hal ini sangat mempengaruhi estetika musikal dari sebuah sajian gending karawitan.

\section{Simpulan}

Berdasarkan analisis data-data dilapangan yang telah dipaparkan pada bagian hasil dan pembahasan di atas terlihat bahwa terdapat faktor internal dan faktor eksternal yang mempengaruhi ketercapaian standar kompetensi pembelajaran Praktik Karawitan Jawa. Faktor internal dan faktor eksternal dilihat berdasarkan indikator unsur garap karawitan menurut Supanggah. Hasil penelitian menunjukkan belum tercapainya standar kompetensi garap karawitan yang di sebabkan oleh faktor internal dan eksternal tersebut. Faktor internal meliputi (1) perbedaan latar belakang budaya setiap mahasiwa, (2) mahasiswa belum mampu dalam menentukan arah garap karawitan, dan (3) mahasiswa belum mampu menentukan pertimbangan garap karawitan. Faktor eksternalnya adalah media pembelajaran yang digunakan, yaitu instrumen gamelan Jawa yang belum lengkap dan kurang berkualitas. Diharapkan dari hasil penelitian ini dapat menjadi bahan evaluasi ke depan dalam upaya meningkatkan standar kompetensi pelaksanaan pembelajaran pada mata kuliah Praktik Karawitan Jawa, Program studi Etnomusikologi, FIB Unmul.

\section{Referensi}

Bandem, I. (2001). Etnomusikologi Penyelamat Musik Dunia. Selonding: Jurnal Etnomusikologi Indonesia, 1(1), 1-7.

Hastanto, S. (2009). Konsep Pathet dalam Karawitan Jawa. Surakarta: Program Pascasarjana bekerja sama dengan ISI Press Surakarta. 
Rustopo, Suparno, T. S., \& Waridi. (2007). Kehidupan Karawitan pada Masa Pemerintahan Paku Buwana X, Mangkunegara IV, dan Informasi Oral. Surakarta: ISI Press.

Sumarsam. (2002). Hayatan Gamelan Kedalaman Lagu, Teori, dan Perspektif. Surakarta: STSI Press Surakarta.

Sumarsam. (2003). Gamelan: Interaksi Budaya dan Perkembangan Musikal di Jawa. Yogyakarta: Pustaka Pelajar.

Supanggah, R. (1995). Etnomusikologi. Yogyakarta: Yayasan Bentang Budaya.

Supanggah, R. (2002) Bothekan Karawitan I. Jakarta: Ford Foundation \& Masyarakat Seni Pertunjukan Indonesia.

Supanggah, R. (2009). Bothekan Karawitan II: Garap. Surakarta: Program Pascasarjana bekerja sama dengan ISI Press Surakarta.

Waridi. (2006). Karawitan Jawa Masa Pemerintahan PB X: Perspektif Historis dan Teoritis. Surakarta: ISI Press Solo. 